Minia Journal of Tourism and Hospitality Research

\title{
The Essential Managerial Competencies for Tourism and Hospitality Graduates: From the Perspective of Tourism and Hospitality Experts in Egypt
}

Wedad Othman a

M. Anter c

${ }^{a}$ Tourism studies Department, Faculty of tourism and Hotels, Minia University

${ }^{b}$ Tourism studies Department, Faculty of tourism and Hotels, Suez Canal University

${ }^{c}$ Tourism studies Department, Faculty of tourism and Hotels, Minia University

\section{Keywords}

Competency Development, Managerial Competencies, Delphi Technique,

Tourism Education,

Egypt.

\begin{abstract}
When identifying and knowing the managerial competencies needed by the industry from fresh graduates and employees, it will be easy for educational institutions to prepare graduates for future entry-level managerial roles by adapting the curriculum according to industry expectations and through training programs. Therefore, this research aims to identify the essential managerial competencies needed from the tourism and hospitality industry graduates for the tourism labor market in Egypt. A Delphi technique was utilized in this research for collecting data from a group of sixty (60) experts and professionals from different tourism and hospitality sectors. Fifty- three (53) of the sixty (60) participants successfully completed the Delphi study. Three rounds of Delphi were conducted in almost thirteen weeks. For processing and analyzing collected data, the Statistical Package for Social Sciences (SPSS) version 26 has been utilized. Results identified four managerial competencies (problem-solving, decision making, client focus, and teamwork) as the most essential competencies with a consensus above $80 \%$. Depending on the findings, it suggests that the tourism and hospitality curriculum can be modified to add these competencies.
\end{abstract}




\section{Introduction}

In recent times, the issue of developing managerial competencies got so much interest, where became one of the essential tools of human resources management and a significant strategic tool in the business environment. This is because of the organizations ' need for well-trained employees managerially to deal with the ongoing changes and adapt to constantly increasing customer requirements besides the noticeable role of developing competencies in promoting the success of staff and institutions (Lawler, 1994; Bergenhenegouwen et.al (1997); Nyhan, (1998); Le Deist and Winterton, 2005 and Bombiak, (2018). This is supported by Ellström and Kock (2008) who mentioned the various benefits of developing competencies for HUMAN resources management practices when developing a certain position or role. These benefits are represented in hiring, advancement, talent management (e.g. the internal and external mobilities and training), and organize work through (e.g. job turnover, and developing jobs).

Likewise, the tourism and hospitality organizations are meeting sundry changes and improvements, including (e.g., the changeable work environment, rising competition globally, the fast progress technological, and ever-changing request types of tourism) Zehrer and Mössenlechner, (2009). These confrontations affect directly the expectations of the employers as regards recruit knowledgeable managers who possess relevant competencies. and staffs Zehrer et al.(2006), where the tourism and hospitality organizations realized these challenges and their impacts on the organizations; consequently, they depend on skillful and knowledgeable employees can manage and cope with the above-mentioned challenges Anderson and Vinceze (2000) and seek to employ graduates with workable and transferrable skills Shakeela et al., (2012).

This was supported by Fallows and Steven (2000); Leiper et al. (2007) and Hobson, (2010) they confirmed employers seek not only particular theoretical skills and knowledge in a specific area but also well-trained graduates, qualified employees with industry pertinent expertise, and related work competencies. In the Egyptian context, the existing literature lacks the information, knowledge, and consensus about the required managerial competencies in the Egyptian tourism and hospitality industry to achieve effective managerial performance.

Therefore, it is becoming necessary to identify and develop the essential needed competencies from graduates and incorporate them into the educational courses Hodges and Burchell, (2003). Tourism and hospitality experts have agelong required that graduates possess the suitable managerial competencies needed to face the ongoing competition Herrera et al., (2003); Agrusa et al., (2004).

\section{Literature Review}

\subsection{Competency Concepts Applied in the Tourism and Hospitality Field}

\subsubsection{Competency Model}

Numerous studies have been conducted on applying the competency models in tourism and hospitality services. Herrera et al., (2003) stated that competency model is a useful tool in the different human resources practices (e.g. hiring, training, competency development, and performance appraising).

Stanišić, (2020) argued that the competency model in the hospitality and tourism establishments can identify the standards for job progress, therefore, selecting 
ideal performance employees. He also indicated that by applying this model, all the essential information on the current and potential employees (e.g. possess the required qualifications and detailed description about their ability to progress) cab be provided.

\subsubsection{Core competencies}

According to Koenigsfeld, (2007) and Roberts, (2003), the competency concept has been applied to various service sectors, including the tourism and hospitality sector for developing a range of core competencies for organizations Hallin and Marnburga, (2007) stated that core competencies are more than tourism resources. (Hamel, 1991) of the view that core competencies permit tourism establishments to provide their products and services to clients with the best performance possible.

According to Nair, et al. (2011) core competencies in the airlines are the fundamental advantage that define its business model in addition to, combine the major processes and non-fundamental processes within the airlines effectively. In another word, this concept differentiates each airline from the others. Most tourism and hospitality establishments serve various segments and categories of clients and providing over one product or service e.g., Easy Jet, carrying travelers between different destinations in Europe but also renting cars, managing hotels, and sailing voyages, and movie theaters Okumus et al., (2019).

\subsection{The Competency Developing in the Tourism and Hospitality Industry:}

According to Forrier et al., (2009), competency development is the organizational activities that promote and preserve the person's competencies and continuous learning. The first step of the competency development process is identifying the required competencies. Draganidis and Mentzas, (2006) defined competency identification is the operation of finding out the needful competencies for perfect and completely effective performance.

Otala, (2008) cited in Hartikainen, (2016) parted the required competencies into two types; the competencies that are needful for the company's existence and the competencies that are needed to succeed in a specific functions or roles.

There are several tools and methodologies utilized for identifying the required competencies for effective job performance including; critical incident techniques, the outcomes of appraising performance, and training needs evaluation De Vos et al., (2015) Delphi study, questionnaires, competency models, interviews, job description/ analysis, and direct noticing Chung and $\mathrm{Wu},(2011)$.

A number of studies Nybo, (2004); Lai and Kaapstad, (2009) and Van der Heijden et al., (2009) mentioned four fundamental HR practices used in the competency development process including; training, on-the-job learning, formal education, and career management. According to Bhardwaj and Punia, (2013) and Apriliant, (2009) there are various ways to develop competencies including; coaching, outside workshops/ seminars, appraisal performance, mentoring, behavior competency model, individual self-studying, on the job training, and competency based formal training program. The next section reviews the recent literature that researched on identifying the required competencies in the tourism and hospitality industry. 


\subsection{The Required Managerial Competencies in the Tourism and Hospitality Industry}

Tavitiyaman et al., (2014) carried out study on the most important managerial competencies required from managers in the hospitality establishments, they identified four essential competencies (leading, teamwork, work morals, and communication).

Morover, Liaman, (2014) identified nine managerial competencies for effective managerial performance in the hospitality industry; communicate effectively, team working, solving problem, client service, think strategically, leadership, Fiscal knowingness, planning and organization.

Hawi et al., (2015) conducted study on the impact of managerial competencies on the airline's organizational performance, using Boyatzis model. They found evidence that competencies (team leadership, problem-solving, strategic thinking, and client focus) are positively related to the organization's performance and that managerial performance may be increased by mentoring on a competency system towards the organization's mission.

Bharwani and Talib, (2016) developed a model of managerial competencies that identified and agreed jointly as an essential competency on the previous literature. These competencies are strategic thinking, invention, systemic thinking, serving orientation, incomes management, conflict management, teamwork and communication.

Wessels et al. (2017) carried out research to know the perspectives know perspectives and opinions of the hospitality employers and stakeholders in South Africa regarding the managerial competencies required from graduates in the hospitality sector. The study revealed a range of competencies; strategic management, human resource management, problem solving, crisis management, communication, and customer service. The authors recommended that tourism higher institutions have to make sure that graduates have the above-mentioned competencies before graduates by Integrate these competencies into fundamental units individually.

\section{Methodology}

Delphi Technique indicates to the Oracle of Delphi in ancient Greece, who could foretell the future Hasson et al., (2000). Patton, (2002) defined Delphi Technique as an operation of using a group of experts, consecutive questionnaires, dominating unknown feedback, and rang consensus. According to Ludwig, (1997) Amos and Pearse, (2008) the Delphi methodology merges both items of quantitative and qualitative approaches that permit collecting data from the experts who share their experience and point of view.

This study utilized the Delphi method as a quantitative methodology for two reasons. First, from reviewing the literature on competencies in the tourism and hospitality field found to be mostly quantitative studies. Second, according to Brady, (2015) the data analysis tools that are used in the quantitative Delphi studies have been developed more than the qualitative studies. Since the Delphi technique origination in the 1950s, it has been applied in many fields including business, education, industrial sectors, and more widely in fields of social science and naturalistic resources McKenna, (1994). The purpose mostly was to range a consensus through; creating ideas and decisions making as regards the complicated aims; organize and structuring the communication within a group; and treating the disagreement or lack of knowledge by collecting individuals' opinions Gupta and Clarke, (1996) and Powell, (2003). The beginning of using the Delphi technique in tourism studies was an internationally wide study conducted by George Washington University in the late 1970s on the future of 
employment in the tourism and hospitality industry. Though applying Delphi in tourism and hospitality still limited, it applies in various tourism disciplines and subjects, such as forecasting tourism product development and evaluating the possible impacts socially and environmentally Guttentag and Smith, (2014). There are many reasons for selecting the Delphi study as a convenient method for the current study, as follows.

1. Huang, (2012) summarized the application of the Delphi technique in the instructional design field; developing curriculum, testing the program's quality, or the educational modules, and identifying the influential trends on the instructional design field.

2. The key characteristics of the Delphi process are providing respondents' anonymity, the feedback controlling process, and using a diversity of statistical methods to analyze and process the data Dalkey, (1972); Ludlow, (1975) and Douglas, (1983).

3. Sandrey and Bulger, (2008) argued that the Delphi method permits experts to suggest or provide recommendations for related competencies and evaluating the authenticity of competencies.

\subsection{Selecting the Experts and Determine the Panel Size:}

Based on Mary Parker Follett's definition cited in Olshfski and Joseph, (1991) an expert is a person who has work expertise in the organizations related to the study object, therefore, he a knowledgeable about the work environment within the organization more than anyone working outside.

Taylor and Judd, (1994) opined that the suitable sample size for similar panel members is ranging between 10 to 15 panelists, also indicated the necessity of increasing the sample size if the members are entirely heterogeneous. Delbecq et al., (1975); Ludwig, 1997; Linstone and Turoff, (2002); Hsu and Stanford, (2007) stated that the Delphi panel sizes range between three to sixty or more panelists.

This study targeted the professional individuals who gained experience by working in the different sectors in the tourism and hospitality industry and have knowledge about the study's subject. The researcher applied a pilot study of ten experts, who have been selected randomly for two reasons ensuring the validity of questionnaire and to nominate potential experts to participate in the study (at least five from each pilot group member). The second procedure was searching for potential experts by using personal networks, professional connections based on recommendations and suggestions of other connections, and professional networks via LinkedIn based on Schubert, (2019) and Wakefield, et al., (2012) methodology. LinkedIn is a social media site has been launched in 2003 designed to build a professional relation network and now becoming a globally recognized instrument used for recruitment, moreover, the LinkedIn profile of users includes their competencies, skills, experience, and work field, which facilitate the search process by using keywords Zide et al., (2012). This feature helped the researcher to screen the potential participants to ensure they met the required criteria. The pilot study and the searching process resulted in identifying a number of 220 potential experts working in various specialties in the tourism and hospitality industry (e.g. airlines, airports, travel and tourism companies, hotels, and government associations. Below the followed actions for selecting the experts of this study;

A recruitment email was sent to 220 candidate experts included a detailed explanation about the current study's nature, aims, and procedures and demographic survey. The objective of this email was to select the appropriate experts to participate in a Delphi study. Every expert was informed that their involvement in this study 
voluntary and the anonymity is guaranteed. The Demographic Survey was submitted by 105 out of 220 candidates participants which included demographic information (e.g. position, sector, educational background, number of years' experience, age, and gender) then the researcher started the process of selecting participants. The researcher analyzed the demographic Survey. A sample of 60 potential participants met the participation conditions and was considered experts because of their knowledge about the study's subject and their years of experience. They were chosen to involve in the current Delphi study from various sectors of the tourism and hospitality industry, such as airlines, airports, hotels, tourism companies, and travel government associations, represented in two sub different panels, the first panel includes professionals in tourism and hospitality and the second panel involves HR professionals working in the tourism and hospitality industry.

\subsection{Data collection}

In this study four questionnaire were used to collect the data study. Based on Dillman et al., (2009) suggestion, the researcher send reminder emails to participants after one week of the launching of every round to raise the response rate of the Delphi study. Two different type of 5-point Likert scale were used in this study (importance level in round II and priority level in round 3) Vagias, (2006).

\subsection{Delphi Rounds}

Critcher and Gladstone, (1998) argued that to reach accuracy in the findings, from two to five rounds is considered suitable. This study includes three rounds to reach a consensus among the selected experts from different tourism and hospitality sectors. Custer et al., (1999) indicated to the First Round as a method to collect specific information about a particular topic from the Delphi panel. According to Ludwig, (1994) in the Second Round, every participant is receiving the next questionnaire and revising the collected items from the compiled information in round one by the researcher. Also, in this round, the descriptive statistics are utilized to analyze the data Von der Gracht, (2012), then conclude these outputs, and redistribute it to participants to launch and finish the third round Stines, (2003). the Third Round is generated from the former two rounds and aims reaching a consensus among the experts on the subject of the study Brady, (2015). based on the former rounds and the purpose of this round is reaching the consensus among the experts

\subsection{Data Processing and Analyzing}

The Delphi method is a reiterated multiple -phase process of controlled feedback Strauss and Zeigler, (1975). These characteristics require collecting, analyzing and summarizing the data through specific time periods to evolve the utilized instrument of every new round in the study Hsu and Sandford, (2007). For this study, collected data were analyzed by SPSS version 26 by calculating frequencies, percentage, means and standard deviation.

\subsection{Reliability and validity}

It is necessary for the researchers to make sure the issue of whether the study is reliable and valid Shadish et al., (2002). Wilson, (2010) pointed the reliability is not adequate without coupling with validity despite its importance for the research. In another way, he argued that validity is a condition of the reliability of the experience. According to Simon, (2011) and Golafshani, (2003) reliability in quantitative studies indicates the availability to replicate the study findings, while the validity is concerned more about the precision of the used measures and clarifies the extent of covering the collected data for the current research point Ghauri and Gronhaug, (2005). To guarantee the validity and reliability of this study, the researcher followed several 
recommended procedures in the Delphi studies literature that may help in achieving these two parameters.

1. According to the Delphi technique literature, the parameter of content and face validity can be achieved. This assumption is based on two reasons. First, the outputs or findings result from a group point of view, which is supposed to be more adequate than an individual opinion. Second, the process depends on experts' opinions from their work experience, which provides confirmed judgments on the study topic. To achieve construct validity Schmidt, (1997) and Okoli and Pawlowski, (2004) argued that the researcher should send the analysis and classification of first-round findings to every expert to conduct reviews. Doing this ensures the validity of experts' definitions and increases the likelihood of mainstreaming the findings to different cases. In this study Face, content, and construct validity were reached through the experts' verdict of the participants who identified the insertion of significant competencies, and the items number and types in every questionnaire Melnyk and Fineout-Overholt, (2015).

2. A pilot study was managed to test the collecting data procedures, illustrate questionnaire items, and correct the weaknesses before conducting the full study Staykova, (2019) and Melnyk and Fineout-Overholt, (2015). Mitchell, (1991) argued that pilot study is a critical factor to design a Delphi study well, which guarantees that the data is reliable and valid.

3. To guarantee the design is valid, a group of standards and methodical procedures were followed to select suitable participants Okoli and Pawlowski, (2004). The selected experts for participation in this study are knowledgeable about the study problem, and collecting data was through sequent rounds, which led to improving content validity and increasing concurrent validity Hasson et al., (2000).

4. According to Hsu and Stanford, (2007) validity can be affected by the responses' depressed rate. Therefore, through the pre-Delphi, the researcher got approval from experts to participate in the Delphi process, in addition to sending reminds via email to supplement the questionnaires on time.

5. For avoiding errors during the data collecting process, the researcher sent emails before beginning each round. These emails included a clear explanation of each round, the links of the questionnaire, instructions for answering each questionnaire, and how to submit the completed questionnaires. Furthermore, experts received their answers after every round as a part of the controlled feedback which allows them to review or modify their responses Okoli and Pawlowski, (2004) and Adler and Ziglio, (1996).

\section{Results}

\subsection{Description of the Sample}

This section displays the participant experts' data in the study. The researcher selected the most proficient experts to represent the sample $(\mathrm{N}=60)$ based on the most experienced in each specialty, besides to other two elements the educational fulfillment and professional accomplishments. The target sample representing various industry segments within the tourism and hospitality sector. The selected sample was divided into two different panels each panel includes 30 experts with various roles in diverse sectors in the tourism and hospitality industry. The following tables show the preDelphi results (participants' demographics data, participants' experience years, and description of the Delphi sample by sectors and positions). 
Table (1) Demographic Data of the Experts $(N=60)$

\begin{tabular}{|l|l|l|}
\hline Data & Frequency & Percentage \% \\
\hline Gender & 51 & $85 \%$ \\
\hline Male & 9 & $15 \%$ \\
\hline Female & \multicolumn{2}{|l|}{} \\
\hline Age Range & 12 & $20 \%$ \\
\hline 25- 34 & 28 & $46.7 \%$ \\
\hline 35- 44 & 12 & $20 \%$ \\
\hline 45-54 & 8 & $13.3 \%$ \\
\hline 55- 65 & \multicolumn{2}{|l}{} \\
\hline Education & 43 & $71.7 \%$ \\
\hline B.S.C & 10 & $16.6 \%$ \\
\hline Diploma & 4 & $6.7 \%$ \\
\hline Master & 3 & $5 \%$ \\
\hline PhD & &
\end{tabular}

Table 1 indicates participants' various backgrounds in demography, and education and explains it in detail. Also, shows that the vast majority of the participants are male (51) by (85\%), while $9(15 \%)$ of the participants identified themselves as female. Also, shows that Panelist ages ranged from 25 to 65 , The highest percentage of age group participation was for the category of 35-44 years with a percentage of $46.7 \%$, while $20 \%$ are between $25-34$ and between 45 and 54 years. Finally, only eight participants with a percentage of $13.3 \%$ are between 55- 65 years. With regards to level of education, table 1 displays that more than half of participants $(71.7 \%)$ have a bachelor's degree, ten experts have diploma (6.1\%), Four of participants have master's degree $(6.7 \%)$, and three hold $\mathrm{PhD}$ degree (5\%).

Table (2) Description participants' Years of experience by panels

\begin{tabular}{|l|l|l|}
\hline Panel One & \multicolumn{2}{|l|}{} \\
\hline Years of Experience & Frequency & Percentage \\
\hline $5-10$ & 0 & $0 \%$ \\
\hline $11-15$ & 3 & $10 \%$ \\
\hline $16-20$ & 5 & 16.7 \\
\hline $21-25$ & 16 & $53.3 \%$ \\
\hline More Than 25 & 6 & $20 \%$ \\
\hline Total & 30 & 100 \\
\hline Panel Two & \multicolumn{2}{|l|}{} \\
\hline Years of Experience & Frequency & Percentage \\
\hline $5-10$ & 5 & $16.7 \%$ \\
\hline $11-15$ & 10 & $33.3 \%$ \\
\hline $16-20$ & 11 & $36.7 \%$ \\
\hline $21-25$ & 4 & $13.3 \%$ \\
\hline More Than 25 & 0 & $0 \%$ \\
\hline Total & 30 & $100 \%$ \\
\hline
\end{tabular}

The previous table shows the participants' years of experience in each panel by frequency and percentage. The years of experience of the panelists of panel 1 range 
from (11- 15 years) category to (more than 25 years) category, and there no panelist has experience range from 5 to 10 years. $53.3 \%$ of the panelists have (21-25) years of experience. This range of experience means that panelists knowledgeable about the basis of the industry. They are aware of the industry's needs, challenges, and emergency changes and they experienced many crises and know the best managerial practices to deal with. Aware of the gap between the industry and academia and have the vision to overcome this gap.

Panel two, panelists' experience ranged from category (5-10 years) to (21 -25 years) category and there no panelist has experience over 25 years. This panel combines panelists up to date with new recruitment techniques based on competencies, new trends of identifying required competencies for each position in each sector of the industry specially the managerial positions, have knowledge about industry needs today and for 5 upcoming years, and dealing with employees directly and evaluate their performance continuously make them knowledgeable about the frequent training needs. They also experienced in evaluating managerial performance, design training programs according to this appraisal, and have experience in training employees from different managerial levels. Also, it is clear that the highest percentage of experience group participation was for the category of 21-25 years, with $33.3 \%$ of participants. Followed by the experience group category 16- 20 with a rate of $26.7 \%$. while twelve participants reported between 11-15 years of experience with a percentage of $20 \%$. Six (10\%) of the 60 panelists possessed over 25 years of experience. Five of the 60 experts have 5-10 years of work experience in the tourism and hospitality industry, with a percentage of $8.3 \%$.

\subsection{Delphi Rounds Results}

\subsubsection{Round One and Round Two}

Round one aimed to identify the required managerial competencies for effective managerial performance in the tourism and hospitality industry in Egypt. 53 out of 60 experts completed the questionnaire with a rate of $(88,3 \%)$. The findings of this round revealed twenty competencies out of 43 identified priorly from the literature review. In round two, the seven participants who withdrew from participation in round one were excluded from round two. The objective of this round is rating each competency of the twenty competencies identified from round one on a 5-point Likert scale $(1=$ Not at all Important and $5=$ Extremely Important). All 53 participants completed round two with a rate of $100 \%$. Experts rated thirteen competencies between extremely important to very important. (8 out of 22 ) of the competencies rated as extremely important including problem-solving $($ mean $=4.98$; standard deviation $=0.14)$, decision making $($ mean $=$ 4.94; standard deviation $=0.23$ ), client focus $($ mean $=4.92$; standard deviation $=0.26$ ), teamwork $(\operatorname{man}=4.91$; standard deviation $=0.29)$, communication $($ mean $=4.83$; standard deviation $=0.38)$, managing time $($ mean $=4.81$; standard deviation $=0.39)$, presentation ideas $($ mean $=4.77$; standard deviation $=0.57$ ), and negotiation $($ mean $=$ 4.68; standard deviation $=0.67$ ) with consensus above $80 \%$. These findings consistent with prior studies (e.g. Huang and Lin, 2010; Christou, 2000).

\subsubsection{Round Three}

After analyzing round two findings and reached the consensus of experts on the most important managerial competencies required from graduates, the researcher developed the questionnaire of round three that included the first thirteen managerial competencies ranged between (extremely important to very important). The purpose of this questionnaire is rating the competencies in terms of priority to focus on during the 
educational process on a 5 -point Likert scale for priority $(1=$ Not a priority and $5=$ Essential). The questionnaire link was sent to fifty- three participants via email to start round three. Experts were also required to give any further feedback. No withdrawals from round three took place. All the experts (53) completed round three with a rate of $100 \%$.

Table (3) Ranking the 13 Managerial Competencies by Priority Level

\begin{tabular}{|l|l|l|l|l|}
\hline \multicolumn{1}{|c|}{ Competency Items } & Mean & Std. Dev. & \% & Attitude \\
\hline Problem-solving & 5.00 & 0 & 100 & Essential \\
\hline Decision-making & 4.96 & 0.19 & 99.2 & Essential \\
\hline Client focus & 4.88 & 0.32 & 97.6 & Essential \\
\hline Teamwork & 4.84 & 0.36 & 96.8 & Essential \\
\hline Communication & 4.18 & 0.39 & 83.6 & High Priority \\
\hline Managing Time & 4.11 & 0.57 & 82.2 & High Priority \\
\hline Presentation ideas & 4.09 & 0.29 & 81.8 & High Priority \\
\hline Negotiation & 4.00 & 0.27 & 80 & High Priority \\
\hline Analytical & 3.39 & 0.49 & 67.8 & Medium Priority \\
\hline Understanding Self and Others & 3.33 & 0.47 & 66.6 & Medium Priority \\
\hline Self-management & 3.30 & 0.46 & 66 & Medium Priority \\
\hline Entrepreneurship & 3.28 & 0.45 & 65.6 & Medium Priority \\
\hline Business fundamental & 2.52 & 0.50 & 50.4 & Low Priority \\
\hline
\end{tabular}

Table 3 shows the experts' rating for the thirteen identified managerial competencies from round two. To illustrate the results, frequencies, mean values, standard deviation, and experts' consensus percentage of each competency were used. The rating range between "Essential to Low priority" level and there are no competencies rated at the "Not a priority" level. Four competencies rated at Essential level; problem- solving, decision making, client focus, and teamwork, while communication, managing time, presentation, and negotiation rated at High priority level with mean score $(4.18,4.11,4.09,4.00)$ respectively. Competencies rated in both (Essential and High priority level) achieved consensus percentage above $80 \%$ and mean score $\geq 4.00$. Experts also rated four competencies at Medium Priority level; analytical, understanding self and others, self-management and entrepreneurship with mean score and consensus percentage less than (4.00), (75\%). Finally, business fundamental competency rated at low priority level with mean score 2.52 and consensus $50.4 \%$.

The findings of this research support previous studies e.g. Alexakis and Jiang, (2019) they argued that the past and recent studies on managerial competencies have defined knowledge, skills, and attitudes in domains such as solving problem, customer service, and communication as the most major competencies that must be acquired by the graduates of tourism and hotels faculties before entering the tourism labor market. Abidin et.al, (2014) study where teamwork and customer service rated as very important competencies for graduates before entering the industry, while communication competency is important. And business fundamental rated as less important competency in terms of acquired by students before graduation. Also, these results are proportional to prior studies (e.g. Buergermeister, (1983) and Goodman and Sprague, (1991) that argued that provided courses in tourism and hospitality education 
should focus on (solve problems, teamwork, and making decisions) competencies for developing the tourism and hospitality students`managerial competencies. Gursoy and Swanger, (2005) revealed ten competencies that hospitality leaders identified as the most important managerial competencies to integrate into the training courses. These competencies consist consistent with three competencies from the current study findings (customer service, oral and written communication, and team building).

\section{Discussion and Recommendations}

The aim of this study is identifying the necessary managerial competencies to merge in a training program for developing the managerial competencies of the tourism and hospitality students in Egypt. To achieve this objective, three Delphi rounds were conducted to reach consensus 60 experts working in various sectors in the Egyptian tourism and hospitality establishments. 53 out of 60 completed the full study. The data out of each round were analyzed by frequencies, percentage, means, and standard deviation using SPSS version 26. The study revealed four competencies (problem solving, decision making, client focus, and teamworking) as essential managerial competencies for tourism and hospitality students to possess before graduation and for working in the tourism labour market.

For universities providing tourism and hospitality education, this study recommends following up with the recent trends of required managerial competencies by the industry, and it is also necessary that the different sectors of the industry itself cooperate with relevant educational institutions. Moreover, it is important to design training program based on identified managerial competencies and integrate these programs into the educational process as learning experiences developing students' competencies. It is critical to improve the cooperation between the service providers and the academia to guarantee that education and training associate with the industry requirements.

\section{Future Studies}

The present study focused on developing the managerial competencies for all the tourism and hospitality students. Other studies could be more specific, investigate on the required managerial competencies from the graduates of the tourism studies department and the hotels studies department.

Moreover, this study used the Delphi technique to identify the required competencies from industry's perspective. Other studies could use mixed methodology (e.g. Delphi technique and interviews) to get to know students' perceptions and expectations on the required competencies in the tourism labour market.

\section{References}

Adler M, and Ziglio E (1996) Gazing into the oracle: the Delphi method and its application to social policy and public health. Jessica Kingsley, Bristol.

Agrusa, J., Tanner, J., and Coats, W. (2004). Hospitality, Restaurant, and Tourism Management Degree Programs and the Issue of Student Preparedness. Journal of Hospitality and Tourism Education, 16(1), 56-63.

Alexakis, G., and Jiang, L. (2019). Industry Competencies and the Optimal Hospitality Management Curriculum: An Empirical Study, Journal of Hospitality and Tourism Education. 
Amos, T. and Pearse, N. (2008): Pragmatic research design: An illustration of the use of the Delphi technique. The Electronic Journal of Business Research Methods, 6(2), 95-102.

Anderson, G.L., and Jones, f. (2000). Knowledge generation in educational administration from the inside out: the promise and perils of site-based, administrator research. Educational Administration Quarterly 36(3), 428-464.

Apriliant, A., Mangundjaya, W., and Poerwadi, N. (2009). Developing Employee's Performance through Competency Assessment (2009). International Conference on Human Resource Development, At: Taioei, Taiwan

Bergenhenegouwen, G., Ten Horn, H., and Mooijman, E. (1997). Competence development - a challenge for human resource professionals: core competences of organizations as guidelines for the devel opment of employees. Industrial and Commercial Training, 29, 55-62.

Bhardwaj, A., and Punia, B.K. (2013). Managerial Competencies and their influence on Managerial Performance- A Literature Review", International Journal of Advance Research in Management and Social Sciences, Volume 2, Issue 5, pp 70-84.

Bharwani, S., and Talib, P. (2017). Competencies of hotel general managers: A conceptual framework. International Journal of Contemporary Hospitality Management, 29 (1), 393-418.

Bombiak, E. (2018). Manager Competencies in the Area of Human Resources Risk Management. International Journal of Contemporary Management Vol. 17 No. 3, pp. 29-49.

Brady, S. R. (2015): Utilizing and adapting the Delphi method for use in qualitative research. International Journal of Qualitative Methods, 14(5). 1-6.

Buergermeister, J (1983) Assessment of the educational skills and competencies needed by beginning hospitality managers', Hospitality Education and Research Journal, Vol 8 No 1 pp $38-53$.

Christou, E. (2000). The Effect of ISO 9000 Certification on Branding of Hotels: An Exploratory Case. Tourism Today, 1(1), 23-33.

Chung, R., and Wu, C. (2011). The identification of personnel director' s competency profile through the use of the job competence assessment method. African Journal of Business Management, 5(2), 405-415.

Chung, R., and Wu, C. (2011). The identification of personnel director' s competency profile through the use of the job competence assessment method. African Journal of Business Management, 5(2), 405-415.

Chung-Herrera, B., Enz, C., Lankau, M., 2003. Grooming future hospitality leaders: a competencies model. Cornell Hotel and Restaurant Administration Quarterly 44 (3), 17-25.

Critcher, C. and B. Gladstone (1998). Utilizing the Delphi technique in policy discussion: a case study of a privatized utility in Britain. Public Administration 76(3): 431-49.

Custer, R. L., Scarcella, J. A., and Stewart, B. R. (1999). The modified Delphi technique: A rotational modification. Journal of Vocational and Technical Education, 15 (2), 1-10.

Dalkey, N. C. (1972). The Delphi method: An experimental study of group opinion. In N. C. Dalkey, D. L. Rourke, R. Lewis, and D. Snyder (Eds.). Studies in the quality of life: Delphi and decision-making, Lexington, MA: Lexington Books (pp. 13-54) 
Dalkey, N., Helmer, O. (1963). An experimental application of the Delphi method to the use of experts, Management Science 9 (3), pp. 458-467.

De Vos, A., De Hauw, S., and Willemse, I. (2011). Competency development in organizations: Building an integrative model through a qualitative study. Vlerick Leuven Gent Management School.

Delbecq, A. L., Van de Ven, A. H., and Gustafson, D. H. (1975). Group techniques for program planning: A guide to nominal groups and Delphi process. Glenview, IL: Scott, Foresman, and Co.

Dillman, Don A., Jolene D. Smyth, and Leah Melani Christian (2009) Internet, Mail, and Mixed-Mode Surveys: The Tailored Design Method, 3rd ed., Hoboken, N.J.: Wiley and Sons.

Draganidis, M. (2006) Competency Based Management; a review of Systems and approaches. Information Management and Computer Security; 14(1):51- 64

Eilstrom, P. E., and Kock, H. (2008). Competence development in the workplace: concepts, strategies, and effects. Asia Pacific Education Review, 9(1), 5-20.

Fallows, S., and Steven, C. (2000). Building employability skills into the higher education curriculum: a university-wide initiative. Education and Training, 42(2), 75-82.doi: 10.1108/00400910010331620.

Forrier, A., Sels, L., and Stynen, D. (2009). Career mobility at the intersection between agent and structure: a conceptual model. Journal of Occupational and Organizational Psychology, 82, 739-759.

Goodman, R. J., Jr., Sprague, L. G., and Jones, W. P. (1991). The future of hospitality education: Meeting the industry's needs. The Cornell Hotel and Restaurant Administration Quarterly, 32(2), 66-70.

Gupta, U., and Clarke, R. (1996). Theory and applications of the Delphi technique: A bibliography. Technological Forecasting and Social Change, 53, 185-211.

Gursoy, D., and Swanger, N. (2005). An industry-driven model of hospitality curriculum for programs housed in accredited colleges of business: Part II. Journal of Hospitality and Tourism Education, 17(2), 46-56.

Guttentag D.A., Smith S.L.J. (2014) Delphi technique, tourism. In: Jafari J., Xiao H. (eds) Encyclopaedia of Tourism. Springer, Cham.

Hallin, C. A., and Marnburga, E. (2007). Knowledge management in the hospitality industry: a review of empirical research. Tourism Management, 29(2).

Hamel, G. (1991). " Competition for Competence and Inter-Partner Learning Within International Strategic Alliances". Strategic Management Journal, Vol. 12, Special Issue: Global Strategy (Summer,1991), pp. 83-103.

Hartikainen, T. (2016), Competence Management as a Tool to Develop New Managers Case: Case company X. LAHTI UNIVERSITY OF APPLIED SCIENCES Master`s Degree Program in International Business Management Thesis.

Hasson, F., and Keeney, S. (2011). Enhancing rigour in the Delphi technique research. Technological Forecasting and Social Change, 78(9), 1695-1704.

Hasson, F., Keeney, S., and McKenna, H. (2000). Research guidelines for the Delphi survey technique. Journal of Advanced Nursing, 32(4), 1008-1015.

Hawi R., Alkhodary D., and Hashem T., (2015). International Journal of Management Sciences Vol. 5 No. 11, pp.723-735.

Hobson, P.J.S. (2010), "Ten trends impacting international and tourism education", (proceeding) Journal of Hospitality and TourismEducation, Vol. 22 No. 1, pp. 4-7. 
Hodges, D., and Burchell, N. (2003). Business Graduate Competencies: Employers' Views on Importance and Performance. Asia-Pacific Journal of Cooperative Education, 4(2), 16-22.

Hsu, C., and Sandford, B. (2007). The Delphi technique: Making sense of consensus. Practical Assessment, Research and Evaluation, 12(10).

Huang, K.Y.C. (2012) College student competency and attitudes in algebra classes: A comparison of traditional and online delivery methods in exponents and polynomials concepts. Ph.D. thesis, Idaho State University.

Koenigsfeld, J.P. (2007), "Developing an Industry Specific Managerial Competency Model for Private Club Mangers in the United States based on Important and Frequently Used Management Competencies, Dissertation.

Lai, L., and Kapstad, J. C. (2009). Perceived competence mobilization: an explorative study of predictors and impact on turnover intentions. International Journal of Human Resource Management, 20, 1985-1998.

Le Diest, D. F., and Winterton, J. (2005). What is competence? Human Resource Development International, 8, 27-46.

Leiper, N., Hobson, J.S.P. and Lewis, P. (2007), "Shall we dance? A step towards revolving the misunderstanding between hospitality and tourism academics and industry practitioners", Journal of Hospitality and Tourism, Vol. 19 No. 4, pp. 45-51.

Linstone, H. A. and M. Turoff. (2002). The Delphi method: techniques and applications.

Ludlow, J. (1975). Delphi inquiries and knowledge utilization. In H. A. Linstone, and M. Turoff (Eds.). The Delphi method: Techniques and applications (pp. 102123). Reading, MA: Addison-Wesley Publishing Company.

Ludwig, B. (1997). Predicting the future: Have you considered using the Delphi methodology? Journal of Extension, 35(5), 1-4.

McCleary, K.W., and Whitney, D. L. (1994). Projecting western consumer attitudes toward travel to six eastern European countries. In M. Uysal (Ed.), Global tourist behavior (pp. 239-256). New York, NY: International Business Press.

McKenna, H. (1994). The Delphi technique: A worthwhile research approach for nursing? Journal of Advanced Nursing, 19, 1221-1225.

Melnyk, B. M., and Fineout-Overholt, E. (2015). Evidence-based practice in nursing and healthcare. A guide to best practice, 3rd ed. Kluwer, Wolter.

Mitchell, V. W. (1991). The Delphi technique: an exposition and application. Technology Analysis and Strategic Management, 3(4), 333-358.

Nair, S., Palacios, M., and Tafur., J. (2011). " Flexibility in airline business models with core competence as an indicator".

Nybo, G. (2004). Personnel development for dissolving jobs: towards a competencybased approach. International Journal of Human Resource Management, 15, 549-564.

Nyhan, B. (1998). Competence development as a key organizational strategy: experiences of European companies. Industrial and Commercial Training, 30 (7), 267-273.

Okoli, C. and Pawlowski, S., 2004. The Delphi method as a research tool: an example, design considerations and applications. Information and Management, 42(1), pp.15-29.

Okumus, F., Altinay, L., Chathoth, P., Koseoglu, M. (2019). Strategic Management for Hospitality and Tourism. London: Routledge. 
Olshfski, D., and Joseph, A. (1991). Assessing Training Needs of Executives Using the Delphi Technique. Public Productivity and Management Review, Vol. 14, No. 3, pp. 297-301.

Otala, L. 2008. Osaamispoman johtamisesta kilpailukyky. Porvoo: WS

Patton, MQ. Qualitative research and evaluation methods. 3rd. Sage Publications; Thousand Oaks, CA: 2002.

Powell, C. (2003). The Delphi technique: Myths and realities. Journal of Advanced Nursing, 41, 376-382.

Roberts, C. (2003). Creating core competencies to develop service excellence. Praxis: Journal of Applied Hospitality Management, 6(1), 102-113.

Sandrey, M., and Bulger, S. (2008). The Delphi method: An approach for facilitating evidence-based practice in athletic training.

Schmidt, R. C. (1997): Managing Delphi surveys using nonparametric statistical techniques. Decision Sciences, 28(3), 763-774.

Schubert, D., 2019. An Instructional Designer Competency Framework for Complex Learning Designs. A dissertation report submitted in partial fulfillment of the requirements for the degree of Doctor of Philosophy. College of Computing and Engineering Nova Southeastern University.

Shadish, W. R., Cook, T. D., and Campbell, D. T. (2002). Experimental and quasiexperimental designs for generalized causal inference. Belmont, CA: Wadsworth Cengage Learning.

Shakeela, A., Breakey, N. and Ruhanen, L. (2012), "Tourism education roles in sustainable tourism development: a case study of SIDS introduction", Journal of Hospitality and Tourism Education, Vol. 24 No. 1, pp. 35-43.

Shariff, N. M. Kayat, K. and Abidin, Z. A. 2014. Tourism and Hospitality Graduates Competencies: Industry Perceptions and Expectations in the Malaysian Perspectives. World Applied Sciences Journal.

Simon, M. K. (2011). Dissertation and scholarly research: Recipes for success. Seattle, WA: Dissertation Success, LLC.

Stanišić, N., and Čerović, S. (2020), Competency model and MULTI-multicriteria decision making in tourism and hotel industry in Serbia. Vol. 12, No. 2, pp. 549564.

Staykova, M. P. (2019). Rediscovering the Delphi Technique: A Review of the Literature. Advances in Social Sciences Research Journal, 6(1) 218-229.

Stines, A. (2003). Forecasting the competencies that will define "best-in-class" business-to-business market managers: An emergent Delphi-hybrid competency forecasting model (Doctoral dissertation).

Strauss H., and Zeigler H. (1975). The Delphi technique and its uses in social science research. Journal of Creative Behavior, 9(4), 253-259.

Taylor, R. E., and Judd, L. L. (1994). Delphi forecasting. In S. F. Witt and L. Moutinho (Eds.), Tourism marketing and management handbook (2nd ed., pp. 535-539). Hemel Hemsptead: Prentice Hall.

Vagias, Wade M. (2006). Likert-type scale response anchors. Clemson International Institute for Tourism and Research Development, Department of Parks, Recreation and Tourism Management. Clemson University.

Van der Heijden, B. I. J. M., Boon, J., Van der Klink, M., and Meijs, E. (2009). Employability enhancement through formal and informal learning: an empirical study among Dutch non-academic university staff members International Journal of Training and Development, 13(1), 19-37. 
Von der Gracht, H. A. (2012). Consensus measurement in Delphi studies: Review and implications for future quality assurance. Technological Forecasting and Social Change, 79, 1525-1536.

Von der Gracht, H. A. (2012). Consensus measurement in Delphi studies: Review and implications for future quality assurance. Technological Forecasting and Social Change, 79, 1525-1536.

Wakefield, J. S., Warren, S. J., and Mills, L. A., (2012). Traits, skills, and competencies aligned with workplace demands: What today's instructional designers need to master. In P. Resta (Ed.), Proceedings of the Society for Information Technology and Teacher Education International Conference 2012 (pp. 31263132).

Wessels, W. (2015). An analysis of management skills within graded establishments in South Africa.

WILSON, J. 2010. Essentials of business research: a guide to doing your research project, SAGE Publication.

Ya-Ling Huang and Chin-Tsai Lin (2010): Management Trainee Core Competencies in the Hospitality Industry: Differences Between Managers and Scholars, Journal of Human Resources in Hospitality and Tourism, 10:1, 1-13

Zehrer, A., and Mössenlechner, C. (2009). Key competencies of tourism graduates: The employers' point of view. Journal of Teaching in Travel and Tourism, 9(3-4), 266-287.

Zehrer, A., Siller, H. and Altmann, A. (2006), “A module system in tourism and leisure education - theoretical and practical perspectives", in $\mathrm{Hu}, \mathrm{C}$. (Ed.), "imagining the future of travel and tourism education", Proceedings of the International Society of Travel and Tourism Educators ISTTE) Conference 2007 in Las Vegas, ISTTE, Las Vegas, NV, pp. 276-285.

Zide, J., Elman, B. and Shahani-Denning, C., (2014). LinkedIn and recruitment: how profiles differ across occupations. Employee Relations, 36(5), pp.583-604. 